\title{
Heavy Metal (Ni, Fe) Concentration in Water and Histopathological of Marine Fish in the Obi Island, Indonesia
}

\author{
Muhammad Aris*, Tamrin \\ Department of Aquaculture, Fisheries, and Marine of Faculty, University of Khairun, Ternate, \\ Indonesia \\ * Corresponding Author: amboasse100676@gmail.com
}

\begin{abstract}
This study aims to determine the content of nickel (Ni) and iron ( $\mathrm{Fe}$ ) as well as histopathological analysis of marine fish in Obi Island waters as a bioindicator of pollution. Besides, water quality conditions were carried out in-situ and ex-situ observations. The parameters observed were temperature, brightness, salinity, $\mathrm{pH}$, dissolved oxygen, nitrate, orthophosphate, ammonia, iron (Fe), and nickel (Ni). The results showed the temperature range between $26.48{ }^{\circ} \mathrm{C}$ to $27.99{ }^{\circ} \mathrm{C}$ below the quality standard or low temperature. The brightness of the relationship between $12 \mathrm{~m}$ and $13 \mathrm{~m}$ is under quality standards. The salinity range between $31.01 \mathrm{ppt}$ to $32.13 \mathrm{ppt}$ below the quality standard. The $\mathrm{pH}$ range is from 8.6 to 8.7 in high or alkaline conditions. Ammonia range between $0.4 \mathrm{mg} / \mathrm{L}$ to $0.7 \mathrm{mg} / \mathrm{L}$ exceeds the quality standard. The range of nitrate between $0.009 \mathrm{mg} / \mathrm{L}$ to $0.012 \mathrm{mg} / \mathrm{L}$ exceeds the quality standard. The range of phosphate between $0.016 \mathrm{mg} / \mathrm{L}$ to $0.019 \mathrm{mg} / \mathrm{L}$ exceeds the quality standard. The DO range between $3.68 \mathrm{mg} / \mathrm{L}$ to $3.77 \mathrm{mg} / \mathrm{L}$ lower than the quality standard. The metal range of $0.6 \mathrm{mg} / \mathrm{L}$ to $0.9 \mathrm{mg} / \mathrm{L}$ exceeds the quality standard. The range of Ni metal between $0.06 \mathrm{mg} / \mathrm{L}$ to $0.09 \mathrm{mg} / \mathrm{L}$ exceeds the quality standard. Histopathological analysis showed that the liver had a hemorrhage, degeneration of blood vessels, vacuolate degeneration, necrosis, or cell death. The muscles experience edema, degeneration of muscle fibers, atrophy of muscle bundles, vacuolar degeneration of muscle Bundles, hemorrhage, infiltration of lymphocytes, and necrosis. The intestine experience infiltration of lymphocytes, melanomacrophages, and necrosis. While $P$. tayenus fish ovaries showed necrosis structure oocytes. This research can be a reference for warning of heavy metal pollution in Obi Island waters, binding to the nature of heavy metals that can accumulate in fish tissue.
\end{abstract}

Keywords: Water quality; Heavy Metal; Pollution; Histopathological; Obi Island.

\section{INTRODUCTION}

Industrial activities that are around the waters will contribute to waste that contains a lot of heavy metals (Al-Masri et al., 2002; Karbassi et al., 2006). One of the mining industry activities on Obi Island is nickel (Ni) mining. Nickel metals are generally associated with other heavy metals such as copper $(\mathrm{Cu})$, arsenic (As), iron $(\mathrm{Fe})$, and platinum (Pt) (Lupankwa et al., 2004; Khan et al. 2019). This heavy metal waste has a great opportunity to enter the waters around the mining area through the river flow (Naji et al. 2010; Hermenean et al. 2015; Paschoalinia et al. 2019).

Materials containing heavy metals that are wasted in the waters are eaten by these microorganisms and chemically transformed into very dangerous compounds. The microorganisms are eaten by the fish so that the heavy metals accumulate in the body tissues of the fish. Small fish become big fish food chains and eventually consumed by humans (Turkmen et al, 2005; Triebskorn et al. 2008).

Heavy metals are not only toxic to plants but also to animals and humans (Baramaki et al. 2012; Parmar et al. 2016; Maurya dan Malik 2018; Hao et al. 2019). This is related to the properties of heavy metals that are difficult to degrade, so they are easily accumulated in the aquatic environment and their presence is naturally difficult to remove, can accumulate in aquatic biota including shellfish, fish, and sediment, have a high half-life in marine biota bodies and have a value a large concentration factor in the body of an organism. Such as iron (Fe) 
and nickel (Ni) (Askary-Sary et al. 2012; Mansouri et al. 2012).

Fe metal is an essential metal whose existence in a certain amount is needed by living organisms, but in excessive amounts can affect living organisms. The high content of Fe metal will have an impact on human health including poisoning (vomiting), intestinal damage, premature aging to sudden death, arthritis, birth defects, bleeding gums, cancer, kidney cirrhosis, constipation, diabetes, diarrhea, dizziness, fatigue, hepatitis, hypertension, insomnia (Youdim, 2001; Abbaspour et al. 2014; Wessling-Resnick 2017). Nickel absorption can be through inhalation, oral, and dermal. Health problems that arise can be in the form of systemic disorders, immunological disorders, neurological disorders, reproductive disorders, developmental disorders, carcinogenic effects, and death (Das et al. 2019; Buxton et al. 2019).

The method of monitoring the pollution of a device by heavy metals has been developed chemically, by determining the level of each pollutant in water or sediment. However, this monitoring is more effective if applied in conjunction with biological monitoring or using living organisms (Rashed, 2001). The use of living organisms as indicators of pollution is called bioindicator (Authman et al. 2015; Sweidan et al. 2015; Miedico et al. 2016). This study aims to determine the content of nickel $(\mathrm{Ni})$ and iron $(\mathrm{Fe})$ as well as histopathological analysis of marine fish in the waters of Obi Island, Indonesia. The histopathological analysis aims to see the level of tissue damage due to the accumulation of heavy metals (Poleksic et al., 2010; Dane dan Şïşman 2020).

\section{MATERIALS AND METHODS}

\section{Study Area}

This research was conducted in the waters of Obi Island, South Halmahera Regency, North Maluku, Indonesia. There are 4 observation stations which are as follows:
- Stations I (Locations 1: 01022.517'S and 127033.934'E. Locations 2: 01021.428 'S and 127035.553'E. Locations 3: 01020.349'S and 127037.593'E)

- Stations II (Locations 1: 01028.082'S and 127025.729'E. Locations 2: 01024.798'S and 127026.938'E. Locations 3: 01023.835 'S and 127031.228'E)

- Stations III (Locations 1: 01036.980'S and 127023.390'E. Locations 2: 01034.469'S and 127024.342'E. Locations 3: 01031.600'S and 127024.304'E. Locations 4: 01030.246'S and 127025.158 'E).

- Stations IV (Locations 1: 01039.899'S and 127024.930'E. Locations 2: 01038.984 'S and $127023.885^{\prime} \mathrm{E}$. Locations 3: 01038.419'S and 127023.822'E).

\section{Water Quality Data Collection}

Observation of water quality data is done in-situ and ex-situ at each station. Water quality parameters observed in-situ are temperature, brightness, salinity, $\mathrm{pH}$, and dissolved oxygen. While the water quality parameters observed ex-situ were nitrate, orthophosphate, ammonia, iron (Fe), and nickel (Ni). For ex-situ observations, water samples are taken based on the Indonesian National Standard (SNI) (KepMenLH, 2004).

\section{Histopathological examination}

The target fish is the catch of the fishermen at each station. Samples taken were liver, muscle, intestine, and gonad fish. Sample handling and histopathological analysis follow Korun and Timur (2008) procedures. Samples of fish organs were fixed with 10\% NBF, dehydrated using multilevel ethanol solution, then cleared using xylene and embedded using paraffin. Next, the sample was cut to a thickness of $5 \mu \mathrm{m}$ with a microtome and stained using hematoxylin and eosin (H\&E). 


\section{RESULTS AND DISCUSSION}

\section{Water quality parameters}

Temperature is one of the most important factors in regulating life processes and the spread of organisms in waters. Water temperature controls the condition of aquatic ecosystems. The increase in temperature causes an increase in the decomposition of organic matter by microbes (Osman dan Kloas, 2010). The results of temperature observations obtained that the temperature in the waters of Station I is
$27.99{ }^{\circ} \mathrm{C}$; station II $27.15{ }^{\circ} \mathrm{C}$; station III $26.48{ }^{\circ} \mathrm{C}$; and station IV $27.21{ }^{\circ} \mathrm{C}$. This result shows that the water temperature is below the optimal range of quality standard or low temperature (KepMenLH, 2004). This can affect the life of biota or aquatic organisms. The temperature has an important role in metabolism for aquatic organisms. Changes in surface temperature can affect the physical, chemical, and biological processes in these waters (Shehata et al. 2017).

Table 1. Water Quality Observation Results

\begin{tabular}{|c|c|c|c|c|c|c|}
\hline \multirow{2}{*}{ Parameters } & \multicolumn{4}{|c|}{ Observation result } & \multirow{2}{*}{$\begin{array}{c}\text { Quality } \\
\text { standards }\end{array}$} & \multirow{2}{*}{ Unit } \\
\hline & I & II & III & IV & & \\
\hline \multicolumn{7}{|l|}{ Physical } \\
\hline Temperature & 27,99 & 27,15 & 26,48 & 27,21 & $28-30^{*}$ & \\
\hline Brightness & 13 & 13 & 12 & 12 & $>5^{*}$ & Meter \\
\hline \multicolumn{7}{|l|}{ Chemical } \\
\hline $\begin{array}{l}\text { Salinity } \\
\mathrm{pH}\end{array}$ & $\begin{array}{l}32,13 \\
8,64\end{array}$ & $\begin{array}{l}32,13 \\
8,6\end{array}$ & $\begin{array}{l}31,01 \\
8,66\end{array}$ & $\begin{array}{l}31,76 \\
8,63\end{array}$ & $\begin{array}{l}33-34^{*} \\
7-8,5^{*}\end{array}$ & $\mathrm{mg} / \mathrm{L}$ \\
\hline $\begin{array}{l}\text { Dissolved } \\
\text { oxygen }\end{array}$ & 3,77 & 3,77 & 3,68 & 3,74 & $>5^{\star}$ & $\mathrm{mg} / \mathrm{L}$ \\
\hline Nitrate & 0,009 & 0,010 & 0,012 & 0,010 & $0,008^{*}$ & $\mathrm{mg} / \mathrm{L}$ \\
\hline Ortophospat & 0,016 & 0,016 & 0,019 & 0,017 & $0,015^{*}$ & $\mathrm{mg} / \mathrm{L}$ \\
\hline Ammonia & 0,4 & 0,4 & 0,7 & 0,5 & $0,3^{*}$ & $\mathrm{mg} / \mathrm{L}$ \\
\hline Iron (Fe) & 0,6 & 0,6 & 0,9 & 0,7 & $0,5^{\star *}$ & $\mathrm{mg} / \mathrm{L}$ \\
\hline Nickel (Ni) & 0,06 & 0,07 & 0,09 & 0,07 & $0,05^{*}$ & $\mathrm{mg} / \mathrm{L}$ \\
\hline
\end{tabular}

Note: $\left({ }^{*}\right):$ Kep-51/MenKLH/2004; $\left({ }^{* *}\right)$ : USEPA, 1986.

Brightness is a level of water transparency that can be observed visually. By knowing the brightness of the waters we can find out to what extent there is still the possibility of the process of assimilation in water, which layers are not turbid, and which is most turbid. Water brightness is very influential in the growth of marine biota. The level of brightness determines the level of photosynthesis of organisms in marine waters (Boyd dan Pine 2010). The results of brightness observations, obtained the brightness of the waters at station I am $13 \mathrm{~m}$; station II $13 \mathrm{~m}$; station III $12 \mathrm{~m}$; and station IV $12 \mathrm{~m}$. The results of this observation are following the quality standards for marine organisms (KepMenLH, 2004).
Salinity is an oceanographic factor that is easily measured but plays an important role in physical, chemical, and biological processes in the ocean, such as the concentration of dissolved oxygen and the spread of marine organisms. Physiologically, salinity is closely related to osmotic pressure adjustment (Boyd dan Pine 2010). Salinity observation results, obtained salinity in waters of the station I am 32.13 ppt; station II 32.13 ppt; station III $31.01 \mathrm{ppt}$; and station IV $31.76 \mathrm{ppt}$. This result shows salinity below the quality standard range (KepMenLH, 2004). Like temperature, the low salinity is thought to be due to being influenced by physical, chemical, and biological aquatic processes (Shehata et al. 2017). 
$\mathrm{pH}$ is one of the chemical parameters that are quite important in monitoring water stability. The results of the observation of $\mathrm{pH}$, it was found that the $\mathrm{pH}$ at station III glasses of water was greater at 8.7; station I 8.6; station II 8.6; and station IV 8.6. These results indicate that the $\mathrm{pH}$ is in high or alkaline conditions (KepMenLH, 2004). Water conditions that are acidic or basic will endanger the survival of the organism because it will cause metabolic and respiratory disorders. Besides that, a very low $\mathrm{pH}$ will cause the mobility of various heavy metal compounds that are toxic to be higher, while a high $\mathrm{pH}$ will increase the concentration of ammonia.

Ammonia analysis results, obtained ammonia in station III is greater that is 0.7 mg / L; station I 0.4 mg / L; station II 0.4 $\mathrm{mg} / \mathrm{L}$; and station IV $0.5 \mathrm{mg} / \mathrm{L}$. These results indicate that ammonia exceeds the range of quality standards (KepMenLH, 2004). Ammonia can be toxic to biota if the levels exceed the maximum threshold. High ammonia levels can be indicated by the presence of organic material pollution from domestic waste, industrial waste, or agricultural fertilizer runoff. The high concentration of ammonia is thought to originate from the waste of mining industry activities at station III. Besides, ammonia compounds in waters can also be derived from the results of animal metabolism and the results of the process of decomposition of organic matter by bacteria (Tayel et al. 2014).

Besides ammonia, the decomposition process by decomposing organisms also produces nitrates. The process is a Nitrification process. Nitrification is the oxidation process of ammonia to nitrite and nitrate. This process is important in the nitrogen cycle and takes place in aerobic conditions. The oxidation of ammonia to nitrite is carried out by Nitrosomonas bacteria while the oxidation of nitrite to nitrate is carried out by Nitrobacter (Effendi, 2003).

Nitrate is the main form of nitrogen in natural waters. Nitrate is an important nutrient in the synthesis of animal and plant proteins (Effendi, 2003). Nitrate analysis results, obtained in station III is greater that is $0.012 \mathrm{mg} / \mathrm{L}$; station I 0.009 $\mathrm{mg} / \mathrm{L}$; station II $0.010 \mathrm{mg} / \mathrm{L}$; and sàtation IV $0.010 \mathrm{mg} / \mathrm{L}$. This result shows that nitrate exceeds the threshold range in the quality standard range (KepMenLH, 2004).

The high concentration of nitrate is thought to be influenced by temperature because high temperatures will cause a higher metabolic rate (Osman dan Kloas, 2010). The higher metabolic rate of phytoplankton can cause nitrates to be absorbed by more phytoplankton so that the measured nitrate gets smaller (Ibrahim dan Ramzy, 2013). Observations (Table 1) show that the temperature is below the optimal range of quality standards or low temperatures (KepMenLH, 2004).

Besides temperature, nitrate concentration is also influenced by $\mathrm{pH}$. If the $\mathrm{pH}$ in water is getting closer to the base it will affect the concentration of nitrate, because the nitrate will tend to be higher when in an alkaline state (Effendi, 2003). The observations (Table 1) show that the $\mathrm{pH}$ is in a high or base condition.

Also, $\mathrm{pH}$ also affects the concentration of orthophosphate in water, if the $\mathrm{pH}$ approaches base then the orthophosphate will tend to be higher in concentration (Effendi, 2003). Orthophosphate analysis results, obtained in station III is greater that is $0.019 \mathrm{mg} / \mathrm{L}$; station I $0.016 \mathrm{mg} / \mathrm{L}$; station II $0.016 \mathrm{mg}$ / $\mathrm{L}$; and station IV $0.017 \mathrm{mg} / \mathrm{L}$. This result shows that Orthophospate exceeds the range of quality standard limits (KepMenLH, 2004). Orthophosphate is one of the most important nutrient compounds at sea. Orthophosphate is needed for the growth and metabolic processes of phytoplankton and other marine organisms in determining water fertility (Ali et al. 2019).

Dissolved oxygen (DO) is needed by all living bodies for breathing, metabolic processes, or exchange of substances which then produce energy for growth and culture (Ali et al. 2019). Also, oxygen is needed for the oxidation of organic and inorganic materials in the aerobic process (Effendi, 2003). DO observation results, obtained DO in the waters of the station I 3.77 mg / L; station II 3.77 mg / L; station 
III $3.68 \mathrm{mg} / \mathrm{L}$; and station IV 3.74. This result shows that DO is lower than the quality standard range (KepMenLH, 2004).

The DO content in the waters of Station III is lower if compared to Station I, Station II, and station IV. This indicates the level of pollution at Station III is greater due to the entry of the mining industry waste into the waters. The impact is more oxygen is used by decomposing bacteria in breaking down mining waste and producing nitrites, nitrates, and ammonia so that the $\mathrm{pH}$ of the water rises or in alkaline conditions. Increasing ammonia concentration can increase $\mathrm{pH}$ (Effendi, 2003).

The results of the iron ( $\mathrm{Fe}$ ) analysis showed the iron in station III is greater that is $0.9 \mathrm{mg} / \mathrm{L}$; station I $0.6 \mathrm{mg} / \mathrm{L}$; station II $0.6 \mathrm{mg} / \mathrm{L}$; and station IV $0.7 \mathrm{mg} / \mathrm{L}$. This result shows that $\mathrm{Fe}$ exceeds the threshold of the quality standard range (USEPA, 1986). The results of the nickel (Ni) analysis show nickel in station III is greater that is $0.09 \mathrm{mg} / \mathrm{L}$; station I $0.06 \mathrm{mg} / \mathrm{L}$; station II $0.07 \mathrm{mg} / \mathrm{L}$; and station IV 0.07 $\mathrm{mg} / \mathrm{L}$. This result shows that nickel also exceeds the threshold of the quality standard range (KepMenLH, 2004).

High concentrations of heavy metals ( $\mathrm{Fe}$ and $\mathrm{Ni}$ ) that exceed the threshold are thought to originate from the activity of the mining industry in the area of Station III. Besides, the concentration of heavy metals is also influenced by temperature and dissolved oxygen. Cooler water temperatures make it easier for heavy metals to soak into the sediment. While high temperatures, heavy metal compounds will dissolve in water. Observations show that the temperature is below the optimal range of quality standards (cold). Low oxygen content causes lower solubility of heavy metals. Dissolved oxygen observations are lower than the optimal range of quality standards (KepMenLH, 2004).

\section{Histopathological analysis}

Heavy metal pollution in waters is a very serious problem because in addition to disrupting the health of aquatic organisms (fish) it also endangers public health as the final consumer (Wang et al. 2005; Gorur et al. 2012; Hosseini et al. 2015; Rose et al. 2015; Alipour et al. 2015; Javed et al. 2016; Luczynska et al. 2018; Ahmed et al. 2019). The results of the study (Table 2) show that the fish used as the object of research are important economically valuable marine fisheries and are used as consumption fish by the coastal communities of Obi Island.

Table 2. Fish species used as research objects

\begin{tabular}{llc}
\hline \multicolumn{1}{c}{ Species } & Sample Organs & Sample Location \\
\hline Plectropomus leopardus & Muscle; Intestine; Heart & Station I \\
Lutjanus griseus & Muscle; Heart & Station I \\
Lutjanus synagris & Muscle; Intestine & Station I \\
Lutjanus campechanus & Muscle; Heart & Station II \\
Lethrinus lentjan & Muscle; Intestine; Heart & Station II \\
Priacanthus tayenus & Ovary; Intestine; Heart & Station II \\
Epinephelus fuscoguttatus & Muscle; Intestine; Heart & Station III \\
Euthynnus affinis & Muscle; Intestine & Station III \\
Selaroides sp & Muscle; Heart & Station III \\
Neoniphon argenteus & Muscle; Intestine; Heart & Station III \\
Caranx Melampygus & Muscle; Heart & Station IV \\
\hline
\end{tabular}

The presence of heavy metals in waters can lead to the natural accumulation process in the body of aquatic organisms. Heavy metals that enter the fish's body cannot be removed anymore from the body, because heavy metals tend to accumulate in the body of the fish. As a result, heavy metals will continue to exist along the food chain. Besides, accumulation can also occur 
through direct absorption of heavy metals contained in the water (Thabet et al. 2019). Exposure to heavy metals results in physiological disorders in the body of the fish which makes the body of the fish have to adapt and can even cause tissue damage in fish organs such as the liver, muscles, intestines, and others (Krishnani et al. 2003; Camargo and Martinez, 2007).

The liver is very susceptible to the influence of chemicals and is the main target organ of toxic substances. This happens because most of the poisons or toxic substances that enter the body and are absorbed by cells will then be brought to the liver by the portal vein of the liver, so that the liver has the potential to experience damage (Abdel -Warith et al. 2011; Hegazi et al. 2015). The results showed that the liver (Fig. 1) had hemorrhage $(\mathrm{H})$, degeneration of blood vessels (DVB), vacuolar degeneration (VD), necrosis or cell death (N). Several previous studies reported the same thing (Athikesavan et al. 2006; El-Naggar et al. 2009; Bhatkar 2011).
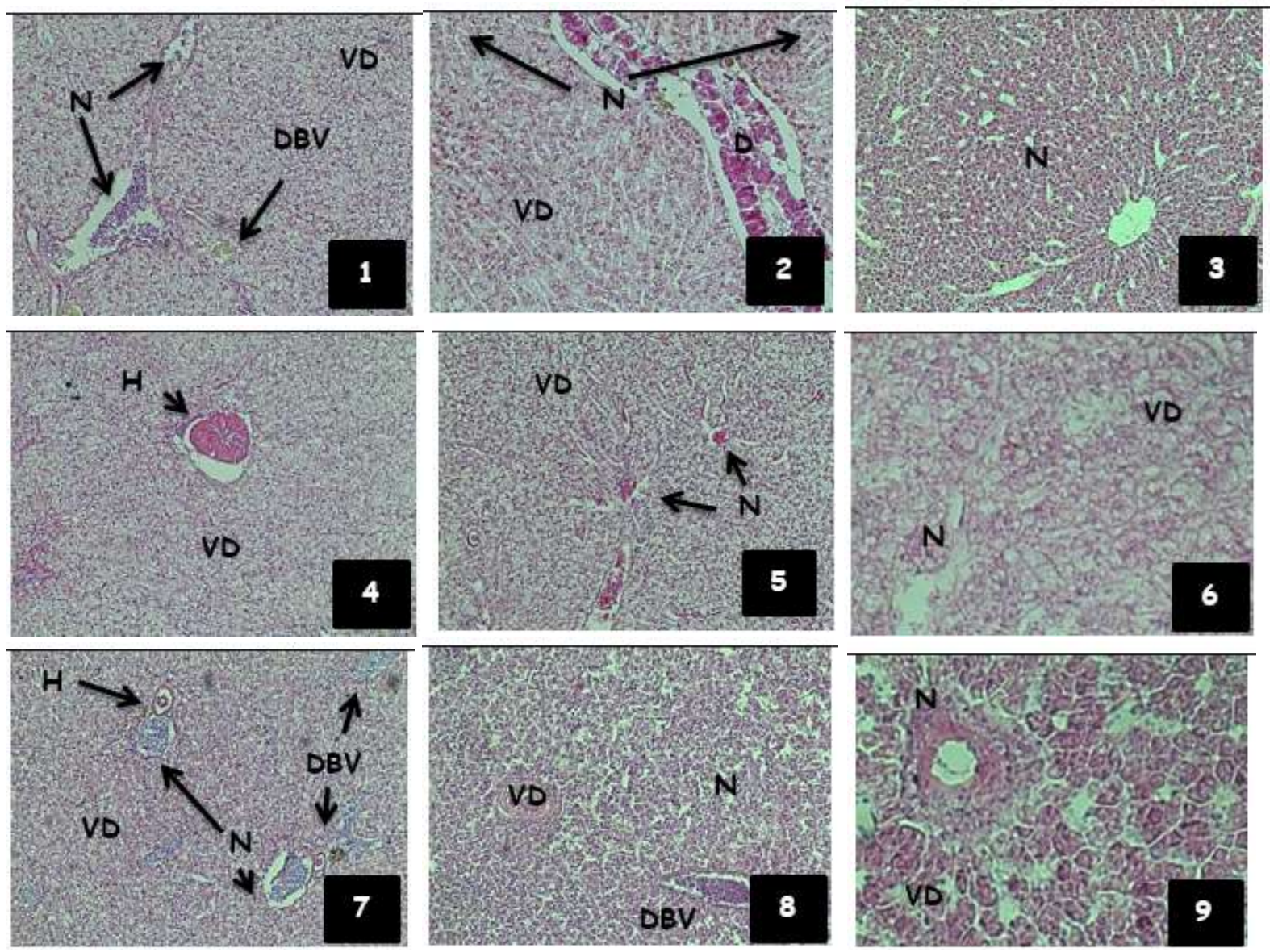

Fig. 1. Photomicrograph of liver: P. leopardus (1); L. griseus (2); L. campechanus (3); L. lentjan (4); E. fuscoguttatus (5); P. tayenus (6); Selaroides sp. (7); N. argenteus (8); C. Melampygus (9).

The results showed the muscle (Fig. 2) experienced edema (E), degeneration of muscle fibers (D), atrophy of muscle bundles $(A)$, vacuolate degeneration of muscle Bundles (VD), hemorrhage $(H)$, infiltration of lymphocytes (IF) and necrosis $(\mathrm{N})$. Accumulation of heavy metals in muscles causes edema or swelling caused by the buildup of fluid in the tissues.
Edema causes muscle tissue to look like it is spreading. The accumulation of heavy metals influences the immune response from blood to the tissues so that the infiltration of lymphocytes occurs. At more severe levels, exposure to heavy metals causes necrosis or death of muscle fiber cells (Kazempoor et al. 2015; Haredi et al. 2020). 

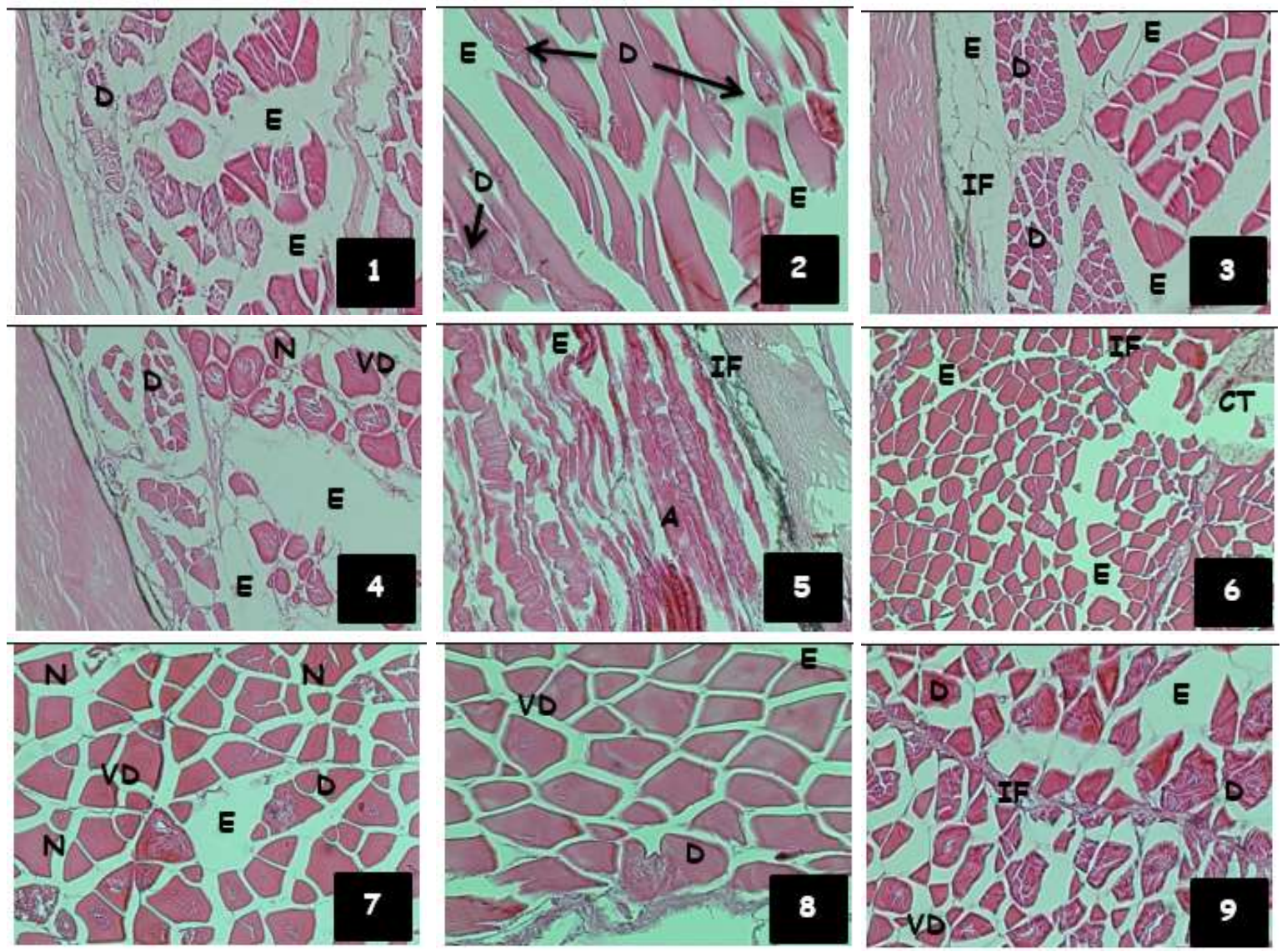

Fig. 2. Photomicrograph of muscle: $P$. leopardus (1); L. synagris (2); L. campechanus (3); L. lentjan (4); E. fuscoguttatus (5); E. affinis (6); Selaroides sp. (7); N. argenteus (8); C. Melampygus (9).

The intestine is an organ that easily accumulates heavy metals (Hanna et al. 2005). The results showed that the intestine (Fig. 3) experienced an infiltration of lymphocytes and melanomacrophages (arrows) and necrosis (N). Infiltration of lymphocytes and melanomacrophages is a form of an immune response to foreign objects including heavy metal exposure (Brochin et al. 2008). Excessive accumulation of heavy metals in intestinal tissue will result in necrosis or cell death (Dohaish, 2018).

Histopathological analysis was also performed on the ovaries of $P$. tayenus fish. Fish reproduction studies can be used as parameters for determining heavy metal pollution (Mansour et al. 2018; Elgaml et al. 2019). The results showed the fish ovary of P. tayenus (Fig. 4) showed necrotic structures of oocytes (Nc). ElMorshedi et al. (2014) and Biswas and Ghosh (2016) reported the accumulation of heavy metals in fish ovaries causing necrosis structure oocytes. Necrosis or cell death in ovaries which are reproductive organs in female fish can threaten the sustainability of fish populations because reproduction is basically a key factor in maintaining population (Ojaveer et al. 2015; Cao et al. 2019). 

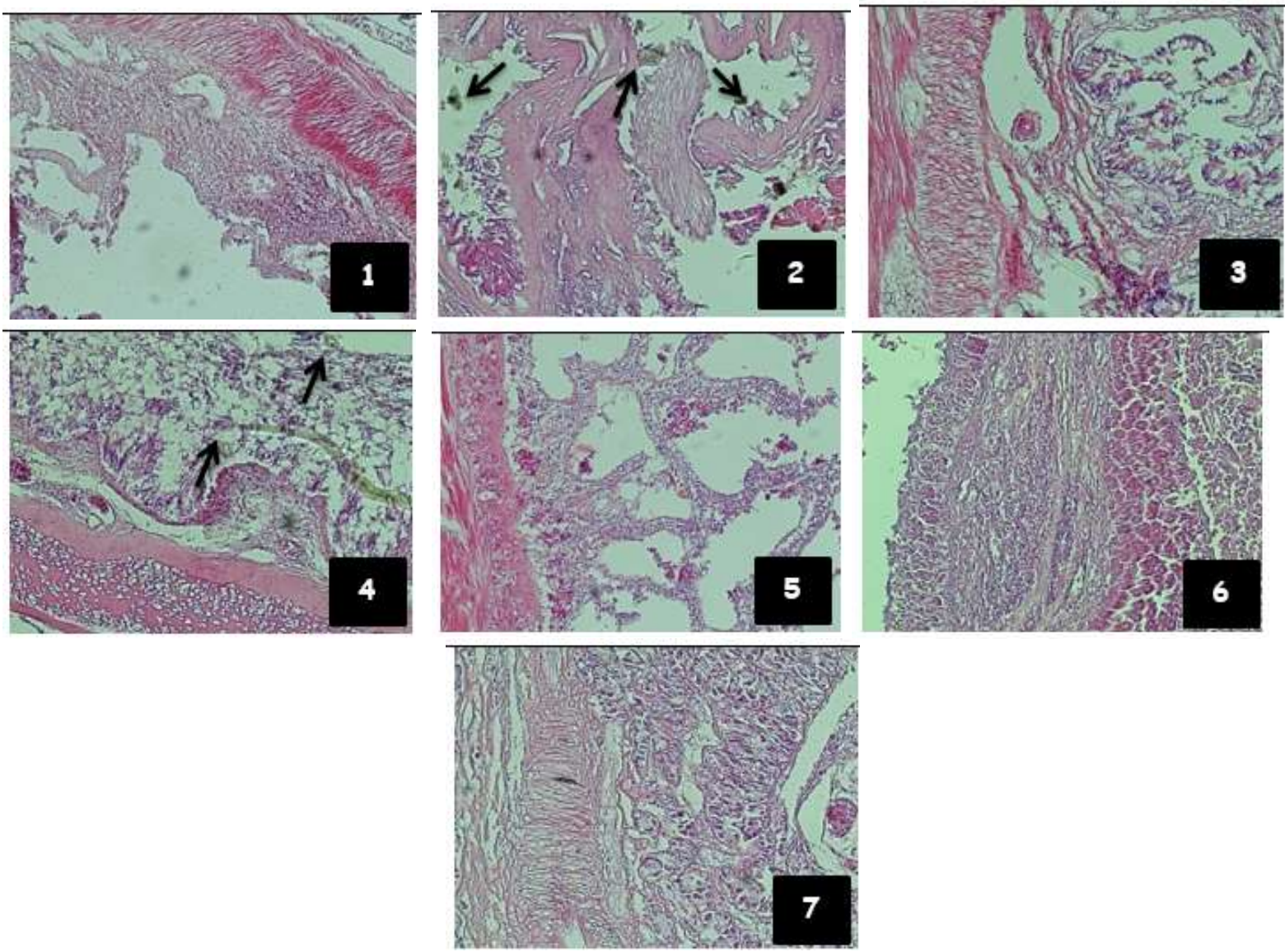

Fig. 3. Photomicrograph of usus: P. leopardus (1); L. synagris (2); L. lentjan (3); E. fuscoguttatus (4); P. tayenus (5); E. affinis (6); N. argenteus (7).

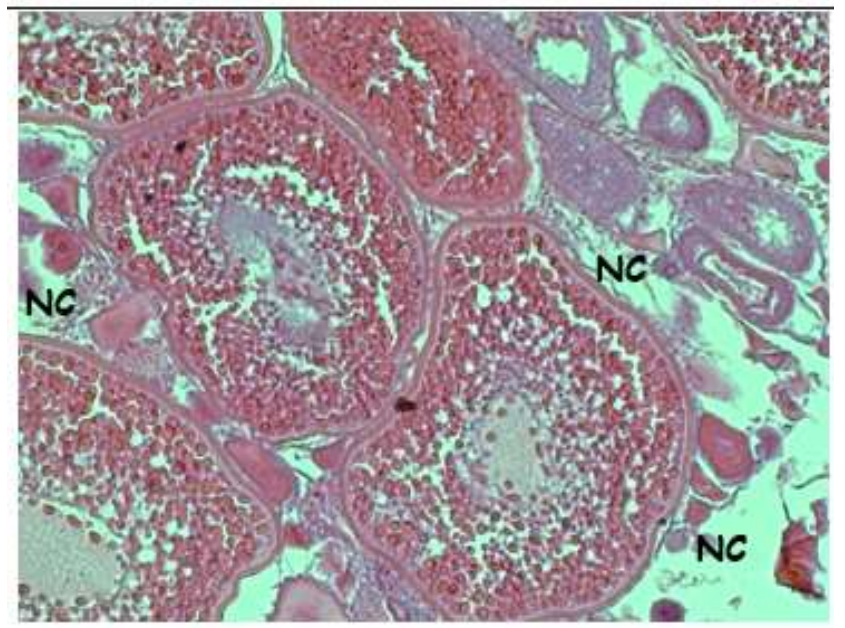

Fig. 4. The histological view of the ovarian structure of $P$. tayenus.

\section{CONCLUSION}

This research can be a reference for warning of heavy metal pollution in Obi Island waters, binding to the nature of heavy metals that can accumulate in fish tissue. Histopathological analysis showed that the liver had a hemorrhage, degeneration of blood vessels, vacuolate degeneration, necrosis, or cell death. The muscles experience edema, degeneration of muscle fibers, atrophy of muscle bundles, vacuolar degeneration of muscle Bundles, hemorrhage, infiltration of lymphocytes, and necrosis. The intestine 
experience infiltration of lymphocytes, melanomacrophages, and necrosis. While $P$. tayenus fish ovaries showed necrosis structure oocytes.

\section{REFERENCES}

Abbaspour N, Hurrell R, Kelishadi R (2014). Review on iron and its importance for human health. J Res Med Sci.19: 164-174.

Abdel-Warith AA, Younis EM, Al-Asgah NA, Wahbi OM (2011) Effect of zinc toxicity on liver histology of Nile Tilapia Oreochromis niloticus. Sci Res Essays 6: 3760-3769

Ahmed ASS, Sultana S, Habib A, Ullah H, Musa N, Hossain MB, Rahman MM, Sarker MSI (2019) Bioaccumulation of heavy metals in some commercially important fishes from a tropical river estuary suggests higher potential health risk in children than adults. PLoS ONE, 14(10): 0219336. DOI: $10.1371 /$ journal.pone.0219336

Al-Masri M, Aba S, Khalil AH, Al-Hares Z (2002) Sedimentation rates and pollution history of a dried lake. Sci. Total Environ. 293: 177-189. DOI: 10.1016/S0048-9697(02)00013-X

Ali H, Khan E, Ilahi I (2019) Environmental Chemistry and Ecotoxicology of Hazardous Heavy Metals: Environmental Persistence, Toxicity, and Bioaccumulation. Journal of Chemistry, DOI: 10.1155/2019/6730305

Alipour H, Poukhabbaz A, Hassanpour M (2015) Estimation of potential health risk for some metallic elements by consumption of fish. Water Qual Expo Health 7(2):179-85. DOI: 10.1007/s12403-014-0137-3

Askary-Sary, A. Beheshti, M. Cadmium, iron, lead, and mercury bioaccumulation in Abu Mullet, Liza abu, different tissues from Karoun and Karkheh Rivers, Khozestan, Iran. Bull. Environ. Contam. Toxicol. 88(2) : 158-161. DOI: $10.1007 / \mathrm{s} 00128-011-0476-8$
Athikesavan S, Vincent S, Ambrose T, Velmurugan B (2006) Nickel induced histopathological changes in the different tissues of freshwater fish, Hypophthalmichthys molitrix (Valenciennes). Journal of Environmental Biology, 27(2): 391395

Authman MMN, Zaki MS, Khallaf EA, Abbas HH (2015) Use of Fish as Bioindicator of the Effects of Heavy Metals Pollution. J Aquac Res Development 6(4). DOI: 10.4172/2155-9546.1000328. https://www.longdom.org/openaccess/use-of-fish-as-bioindicator-ofthe-effects-of-heavy-metals-pollution2155-9546-1000328.pdf

Bhatkar NV (2011) Chromium, Nickel, and Zinc Induced Histopathological Alterations in the Liver of Indian Common Carp Labeo rohita (Ham.). JASEM, 15(2): 331 - 336

Biswas S, Ghosh AR (2016) Lead-induced histological alterations in ovarian tissue of freshwater teleost Mastacembelus pancalus (Hamilton). International Journal of Advances in Scientific Research, 2(01): 045-051

Buxton S, Garman E, Heim KE, LyonsDarden T, Schlekat CE, Taylor MD, Oller AR (2019). Concise Review of Nickel Human Health Toxicology and Ecotoxicology. Inorganics, 7(89): 138. DOI: 10.3390/inorganics7070089

Boyd CE, Pine H (2010) Application of agrometeorology to aquaculture and fisheries. In: Guide to Agricultural Meteorological Practices (GAMP), Chapter 13. (PP. 1-25). Geneva, Switzerland: World Meteorological Organization.

https://www.wmo.int/pages/prog/wcp/ agm/gamp/documents/WMO_No134 en.pdf

Brochin R, Leone S, Phillips D, Shepard N, Zisa D, Angerio A (2008) The Cellular Effect of Lead Poisoning and Its Clinical Picture. The Georgetown Undergraduate J. Health Sci. 5(2). 
Camargo MMP, Martinez CBR (2007) Histopathology of gills, kidney, and liver of a neotropical fish caged in an urban stream. Neotrop Ichthyol. 5(3): 327-336

Cao J, Wang G, Wang T, Chen J, Wenjing G, Wu P, He X, Xie L (2019) Copper caused reproductive endocrine disruption in zebrafish (Danio rerio). Aquatic Toxicology, 211: 124-136. DOI: 10.1016/j.aquatox.2019.04.003

Dane H, Şïşman T (2020) A morphohistopathological study in the digestive tract of three fish species influenced with heavy metal pollution. Chemosphere, 242: 125212. DOI: 10.1016/j.chemosphere.2019.12521 2

Das KK, Reddy RC, Bagoji IB, Das S, Bagali S, Mullur L, Khodnapur JP. Biradar MS (2019). The primary concept of nickel toxicity - an overview. J Basic Clin Physiol Pharmacol, 30(2): 141-152. DOI: 10.1515/jbcpp-2017-0171

Dohaish EJAB (2018) Impact of some heavy metals present in the coastal area of Jeddah, Saudi Arabia on the gills, intestine, and liver tissues of Lutjanus monostigma. Journal of Environmental Biology, 39: 253-260. DOI: $\quad 10.22438 / \mathrm{jeb} / 39 / 2 / P R N-121$ http://www.jeb.co.in/index.php?page $=$ abstract\&issue $=201803$ mar18\&nu mber $=17$

Effendi H (2003) Telaah Kualitas Air Bagi Pengelolaan Sumber Daya dan Lingkungan Perairan. Penerbit Kanisius. Yogyakarta. https://books.google.co.id/books?id= HyjDhfW87B0C\&printsec=copyright\& $\mathrm{hl}=\mathrm{id} \# \mathrm{v}=$ onepage $\& \mathrm{q} \& \mathrm{f}=$ false

El-Morshedi M, Alzahrani I, Kizilbash NA, Abdeen A, El-Shebbly A, El-Berri A (2014) Effect of Heavy Metal Pollutants on Fish Population in two Egyptian Lakes. International Journal of Advanced Research, 2(1): 408417. (ISSN 2320-5407). www.journalijar.com

http://www.journalijar.com/article/103 9/effect-of-heavy-metal-pollutantson-fish-population-in-two-egyptianlakes/

El-Naggar AM, Mahmoud SA, Tayel SI (2009) Bioaccumulation of Some Heavy Metals and Histopathological Alterations in Liver of Oreochromis niloticus concerning Water Quality at Different Localities along the River Nile, Egypt. World Journal of Fish and Marine Sciences 1(2): 105-114. Corpus $\quad$ ID: 85932062. https://www.semanticscholar.org/pap er/Bioaccumulation-of-Some-HeavyMetals-and-in-Liver-ElnaggarMahmoud/32f90f4f673b4458733bcd 9a493820a7cb5f79fc

Elgaml SA, Saad TT, Hamed MF, Zaki VH (2019) Effects of heavy metal pollutants on the reproduction of Nile tilapia. IJFAS, 7(5): 542-547. http://www.fisheriesjournal.com/archi ves $/$ ?year $=2019 \&$ vol $=7 \&$ issue $=5 \&$ par $\mathrm{t}=\mathrm{G} \&$ Articleld $=2027$

Gorur FK, Keser R, Akcay N, et al. (2012) Radioactivity and heavy metal concentrations of some commercial fish species consumed in the Black Sea Region of Turkey. Chemosphere 87:356e61.

DOI: 10.1016/j.chemosphere.2011.12.022

Hanna MI, Shaheed IB, Elias NS (2005) A Contribution on Chromium and Lead Toxicity in Cultured (Oreochromis niloticus). Egyption J. Aquat. Biol. Fish., (9): 177-209

Haredi AMM, Mourad M, Tanekhy M, Wassif E, Abdel-Tawab HS (2020) Lake Edku pollutants induced biochemical and histopathological alterations in muscle tissues of Nile Tilapia (Oreochromis niloticus). Toxicol. Environ. Health. Sci. DOI: 10.1007/s13530-020-00042-w

Hegazi MA, El Haleim SZA, Sirdah MM, Mwafy SN (2015) Oxidative stress in liver and white muscles of Nile Tilapia as responses to a polluted area in the Nile River. Egypt J Exp Biol Zool, 11: 23-36. 
https://www.bibliomed.org/?mno=189 781

Hermenean A, Damache G, Albu P, Ardelean A, Ardelean G, Ardelean DP, Horge $M$, Nagy $T$, Braun $M$, Zsuga $M$, Kéki $S$, Costache $M$, Dinischiotu A (2015) Histopathological alterations and oxidative stress in liver and kidney of Leuciscus cephalus following exposure to heavy metals in the Tur River, North-Western Romania. Ecotoxicology and Environmental Safety 119 : 198-205. DOI: 10.1016/j.ecoenv.2015.05.029

Hosseini M, Nabavi SMB, Nabavi SN, Pour NA (2015) Heavy metals (Cd, $\mathrm{Co}, \mathrm{Cu}, \mathrm{Ni}, \mathrm{Pb}, \mathrm{Fe}$, and $\mathrm{Hg}$ ) content in four fish commonly consumed in Iran: risk assessment for the consumers. Environ Monit Assess, 187:237. DOI: 10.1007/s10661-0154464-Z

Ibrahim LA, Ramzy EM (2013) Water quality and its impact on Tilapia zilli (case study) Qarun lake-Egypt. Int Water Technol J, 3: 170-191. https://pdfs.semanticscholar.org/fbd6 /4042d8dac5ea551fa61472021d1 af4 $312 \mathrm{fcb} . \mathrm{pdf}$

Javed M, Ahmad I, Usmani N, Ahmad M (2016) Studies on biomarkers of oxidative stress and associated genotoxicity and histopathology in Channa punctatus from the heavy metal polluted canal. Chemosphere 151 : 210-219 DOI: 10.1016/j.chemosphere.2016.02.080

Kale VS (2016) Consequence of temperature, ph, turbidity, and dissolved oxygen water quality parameters. Int J Adv Res Sci Eng Technol, 3: 186-190. https://iarjset.com/upload/2016/augu st-16/IARJSET\%2034.pdf

Karbassi AR, Bayati I, Moattar F (2006) Origin and chemical partitioning of heavy metals in riverbed sediments. Int. J. Environ. Sci. Technol. 3: 3542. DOI: $10.1007 / B F 03325905$
Kazempoor R, Asl AHK, Motallebi AA, Alaie E, Marammazi GJ, Roshani A (2015) Histopathological changes of water-soluble fraction of Iranian crude oil in the muscle of yellowfin seabream (Acantopagrus latus). Int $\mathrm{J}$ Biosci, 6: 451-459. Corpus ID: 212583868.

https://www.semanticscholar.org/pap er/Int.-J.-Biosci-Kazempoor-

Asl/f5e516560bf059ebbddc8eb54f9a 8424a8c47d5d?p2df

Khan UA, Kujala K, Nieminen SP, Räisänen ML, Ronkanen A (2019) Arsenic, antimony, and nickel leaching from northern peatlands treating mining influenced water in a cold climate. Science of the Total Environment 657: 1161-1172 DOI: 10.1016/j.scitotenv.2018.11.455

Korun, J., And G. Timur. 2008. Marine Vibrios Associated With Diseased Sea Bass (Dicentrarchus labrax) In Turkey. Journal of Fisheries Sciences. 2(1): 66-76. DOI: 10.3153/jfscom.2008

Krishnani KK, Azad IS, Kailasam M, Thirunavukkarasu AR, Gupta BP, Joseph KO, Muralidhar M, Abraham M (2003) Acute Toxicity of Some Heavy Metals to Lates calcarifer Fry with a Note on Its Histopathological Manifestations. Journal Of Environmental Science And Health, 38(4): 645-655

Luczynska J, Paszczyk B, Luczynski MJ (2018) Fish as a bioindicator of heavy metals pollution in the aquatic ecosystem of Pluszne Lake, Poland, and risk assessment for consumer's health. Ecotoxicology and Environmental Safety, 153: 60-67. DOI: 10.1016/j.ecoenv.2018.01.057

Lupankwa, K., Love, D., Mapani, B.S., Mseka, S., 2004. Impact of a base metal slimes dam on water systems, Madziwa Mine, Mazowe Valley, Zimbabwe. Physics and Chemistry of the Earth 29, 1145-1151. DOI: 10.1016/j.pce.2004.09.017 
Mansour HAA, El-kady MAH, Almaaty AHA, Ramadan AM (2018) Effect of Environmental Pollution on Gonads Histology of the Nile Tilapia, Oreochromis niloticus from Lake Manzala, Egypt. Egyptian Journal of Aquatic Biology \& Fisheries, 22(5): 563-572

Mansouri B, Ebrahimpour M, Babaei H (2012) Bioaccumulation and elimination of nickel in the organs of blackfish (Capoeta fusca). Toxicol. Ind. Health. 28, 361-368

Menteri Negara Lingkungan Hidup, Indonesia (2004) Keputusan Menteri Negara Lingkungan Hidup Nomor 51 Tahun 2004 tentang Baku Mutu Air Laut Untuk Biota Laut. Jakarta.

Miedico O, Ferrara A, Tarallo M, Pompa C, Bisceglia D, Chiaravalle AE (2016) Hazardous and essential trace elements profile in the different soft tissues of Lithophaga lithophaga (Linnaeus, 1758) from Southern Adriatic Sea (Italy)," Toxicological \& Environmental Chemistry, 98(8): 877-885. 10.1080/02772248.2015.1128434

Naji A, Ismail A, Ismail AR (2010) Chemical speciation and contamination Assessment of $\mathrm{Zn}$ and $\mathrm{Cd}$ by sequential extraction in surface sediment of Klang River. Malaysia. Microch. Jour, 95: 285292.

DOI:

10.1016/j.microc.2009.12.015

Ojaveer $\mathrm{H}$, Tomkiewicz J, Arula T, Klais R (2015) Female ovarian abnormalities and reproductive failure of autumnspawning herring (Clupea harengus Membras) in the Baltic Sea. ICES J. Mar. Sci., 72: 2332-2340

Osman AG, Kloas W (2010) Water quality and heavy metal monitoring in water, sediments, and tissues of the African catfish Clarias gariepinus (Burchell, 1822) from the river Nile. Egypt $J$ Environ Protect,1: 389-400. DOI: 10.4236/jep.2010.14045

Paschoalini AL, Savassi LA, Arantes FP, Rizzo E, Bazzoli N (2019) Heavy metals accumulation and endocrine disruption in Prochilodus argenteus from a polluted neotropical river. Ecotoxicology and Environmental Safety 169 (2019) 539-550. DOI : 10.1016/j.ecoenv.2018.11.047

Poleksic V, Lenhardt M, Jaric I, Djordjevic D, Gacic Z, Cvijanovic G, Raskovic B (2010) Liver, Gills, And Skin Histopathology And Heavy Metal Content Of The Danube Sterlet (Acipenser ruthenus Linnaeus, 1758). Environmental Toxicology and Chemistry, 29(3): 515-521

Rashed MN (2001) Cadmium and Lead levels in fish (Tilapia nilotica) tissues as biological indicators for lake water pollution. Environ.Monit. and Assess. 68(1):75-89

Rose M, Fernandes A, Mortimer D, Baskaran C (2015) Contamination of fish in UK freshwater systems: Risk assessment for human consumption. Chemosphere, 122: 183-189

Rothig T, Ochsenkuhn MA, Roik A, Van Der Merwe R, Voolstra CR (2016) Long-term salinity tolerance is accompanied by major restructuring of the coral bacterial microbiome. Mol. Ecol. 25, 1308e1323. DOI: $10.1111 / \mathrm{mec} .13567$

Shehata S, Ghanem MH, Ragab AM (2017) Effect of some environmental factors on the food and feeding habits of the cichlid fish, Tilapia zillii, inhabiting Lake Qarun, Egypt. Egypt Acad J Biol Sci, 9: 55-70. DOI: 10.21608/eajbsz.2017.13457.

https://www.researchgate.net/publica tion/327693945_Effect_of_Some_En vironmental_Factors_on_the_Food and Feeding Habits of the Cichlid Fish_Tilapia_zillii_Inhabiting_Lake_ Qarun_Egypt

Sweidan AH, El-Bendary N, Hegazy OM, Hassanien AE, Snasel V (2015) Water pollution detection system based on fish gills as a biomarker. Procedia Comput. Sci. 65: 601-611. DOI: 10.1016/j.procs.2015.09.004 
Tayel SI, Ahmed NAM, EL-Hossiny MA (2014) Impact of diffused pollution on histological and hematological properties of Mugil cephalus and Mugil capito collected from lake Manzalah, Egypt. Int J Environ Sci Eng 5: 51-67. http://www.pvamu.edu/engineering/w p-content/uploads/sites/30/lJESEvol-5-Issue-5.pdf

Thabet IA, Tawadrous W, Samy AM (2019) Pollution induced change of liver of Oreochromis niloticus: metals accumulation and histopathological response. World Journal of Advanced Research and Reviews 02(02), 025-035.

10.30574/wjarr.2019.2.2.0020

Triebskorn R, Telcean I, Casper H, Farkas A, Sandu C, Stan G, Colărescu O, Dori T, Köhler H (2008) Monitoring pollution in River Mureş, Romania, part II: Metal accumulation and histopathology in fish. Environ Monit Assess 141: 177-188. DOI: 10.1007/s10661-007-9886-9

Turkmen A, Turkmen M, Tepe YI, Akyurt I (2005). Heavy metals in three commercially valuable fish species from Iskenderun Bay, Northern East Mediterranean Sea, Turkey. Food
Chemistry, 91, 167-172. DOI: 10.1016/j.foodchem.2004.08.008

USEPA (1986) Quality criteria for water EPA 440/5-86-001. The United States Environmental Protection Agency, Office of Water Regulations and Standards, Washington DC.

Velusamy A, Satheesh Kumar P, Ram A, Chinnadurai S (2014) Bioaccumulation of heavy metals in commercially important marine fishes from Mumbai Harbor. India. Mar. Pollut. Bull., 81: 218e224. DOI: 10.1016/j.marpolbul.2014.01.049

Wang X, Sato T, Xing B, Tao S (2005) Health risks of heavy metals to the general public in Tianjin, China via consumption of vegetables and fish. Science of the Total Environment, 350: 28 - $37 . \quad$ DOI: 10.1016/j.scitotenv.2004.09.044

Wessling-Resnick M (2017) Excess iron: considerations related to the development and early growth. Am. J. Clin. Nutr. 106: 1600S-5S. DOI: 10.3945/ajcn.117.155879.

Youdim MBH (2001) Deficiency and Excess of Iron in Brain Function and Dysfunction. Nutrition Reviews, 59(8): 83-87. DOI: /10.1111/j.17534887.2001.tb05506.x 